\title{
OLD AND NEW IN THE STATISTICS OF THE MINISTRY OF DEFENSE
}

\section{V.Zatsepin}

In 2015, the Russian military agency made a major step forward in its statistics having published early this year the annual statistical book for the first time since 1914. However, as early as at the stage of preparing the above book which is meant to expand largely departmental statistics represented before only by the data on the number of pensioners of the Ministry of Defense compilers encountered the traditional domestic obstacle - a secrecy barrier - which made their publication efforts less valuable.

After a year and half break, the 2014 and 2015 official departmental statistics provided for by Cl.7.1 of the Federal Plan of Statistical Work and dealing with the number of military pensioners was published in the Open Data section of the Web-site of the Ministry of Defense of the Russian Federation ${ }^{1}$.

According to the published data, as of 1 January 2015 the number of pensioners of the Ministry of Defense stood at 1156352 people, including 992334 persons $(85.8 \%)$ receiving length-of-service pensions, 35903 persons (3.1\%) -- disability pensions and 128115 persons (11.1\%) - survivor's pensions. In 2014, the number of pensioners receiving length-of-service pensions increased by 20187 people (2.1\%), which can be explained by registration of military pensioners of the Crimea Federal District (25013 persons) and growth in the number of military pensioners in the Far Eastern Federal District (an increase of 1174 pensioners). In other federal districts and the Baltic States, the number of pensioners of the Ministry of Defense decreased in the past year. It is to be noted that in the past decade ${ }^{2}$ from 1 January 2006 the number of pensioners of the Ministry of Defense changed insignificantly, having grown by $1.2 \%$ (13752 persons)

A larger part of pensioners and disabled persons registered with the Ministry of Defense lives in the Central Federal District (39.5\% with 9.3\% in Moscow), while a smaller one, in the Far Eastern District (5.4\%), the Crimean Federal District (2.9\%) and the Baltic States (2.2\%).

It is to be noted that the above data were published on the site of the military agency on 23 April, that is, unusually early for 2015 (the deadline for provision of the data under the plan of statistical work is 21 June) and, undoubtedly, that is good ${ }^{3}$. However, the bad thing is that that official departmental statistics was paradoxically ignored in preparation of the Annual Statistical Book, a new statistical publication of the Ministry of Defense of the Russian Federation.

The 2013 Annual Statistical Book of the Ministry of Defense of the Russian Federation which was called by V. Gerasimov, General of the Army, Chief of

1 The number of pensioner, including disabled persons registered with and receiving pensions from the Ministry of Defense of the Russian Federation. URL: http://stat.mil.ru/files/ morf/opendata/7704252261-MORF-3.3.csv (date of application: 24.04.2015).

2 On Pensions and Other Things... // Krasnaya Zvezda. 2006. 29 November.

3 On 26 June the Ministry of Defense reported about publication of those data at the Website of Russia's open data. 
the Joint Staff of the Russian Federation "the Army in Figures" ${ }^{1}$ at the meeting with foreign military attaches later last year appeared in the Financial and Economic Activities Section of the official Web-site of the Ministry of Defense on 26 January $2015^{2}$. However, the above publication meant to renew the tradition of Russian military statistics ${ }^{3}$ broken in 1914 encountered from the very beginning with well-known obstacles, that is, classification as secret of those materials which are known to everybody. It is for that reason the statistical book includes no data on the number of military servicemen, civilian personnel and, probably, pensioners of the Military of Defense. The latter is particularly illustrative as the relevant number (1127671 people) as of 1 January 2013 was published in the open data format in October of the same year. Such practices made the efforts both of the senior officials of the military agency to overcome explicit statistical backwardness of the past 100 years and all employees of the Ministry of Defense who engage in collection, processing and preparation of departmental data for publication less valuable.

It is to be reminded that in the last few days of 2013 covered by the above statistical book some strange discrepancies in the statistical data on defense issues were observed.

The most curious one took place at the enlarged meeting of the collegium of the Ministry of Defense on 10 December 2013 when with a half an hour break the President of the Russian Federation and the Minister of Defense gave different numbers of contract soldiers and sergeants: 205,100 persons and "about 220,000 persons", respectively. The data of the Minister of Defense happened to be more accurate than those which were available to the Administration of the President of the Russian Federation and two days later in his Address to the Federal Assembly the President of the Russian Federation cited the number of "up to 220,000 persons" ${ }^{4}$. Eventually, in a month and a half the number of those servicemen stabilized in the annual report of the military agency at the level of "over 225,000"

The existing practice of state management without relying on the official statistics resulted that year in discrepancies in other important issues, as well. So, Yu. Borisov, Deputy Defense Minister speaking at the round table - The Implementation of Measures of the State Defense Order - held on 20 November declared that by the end of 2013 forecast estimates of equipment of the armed forces with modern weaponry would be as follows: the Air Force (42\%), the Navy (slightly over 50\%), the Ground Troops (about 17\%), the Aerospace Defense Forces (about 57\%) and the Strategic Nuclear Forces (about $40 \%$ ). Almost three weeks later, in the report of S. Shoigu, Minister of Defense at the abovementioned collegium of the Ministry of Defense held on 10 December 2013 most estimates cited by Yu. Borisov were adjusted (except for the Air Force where the estimate of $42 \%$ was left unchanged)

1 The Ministry of Defense of the Russian Federation is preparing publication of the unique statistical book: The Army in Figures. URL: http://function.mil.ru/news_page/country/more. htm?id=12003607@egNews (the date of application: 10.12.2014).

2 The annual statistical book. 2013. Moscow: The Ministry of Defense of the Russian Federation, 2015. 116 p.p. URL: http://stat.mil.ru/files/morf/statistika_\%202013.pdf (the date of application: 13.03.2015).

3 See: The 1912 Military Statistical Book. St. Petersburg: Publication of the General Headquarters, 1914.

4 The President's Address to the Federal Assembly. Moscow, 12 December 2013.

5 The Operations Plan of the Ministry of Defense. The 2013 Report. URL: http://mil.ru/files/ files/result2013/01-planMO2013.html (дата обращения: 22.01.2014). 
upwards: the Navy (52\%), the Ground Troops (21\%), the Aerospace Defense Forces (62\%) and the Strategic Nuclear Forces (45\%). The highest statistical achievement was cited on the same day by V.Gerasimov, General of the Army, Chief of the Joint Staff of the Russian Federation in his speech before foreign military attaches. If one believes the Joint Staff's data which generally coincide with the version made public by the Minister of Defense, the share of modern samples in the Strategic Nuclear Forces may amount to $62 \%{ }^{1}$. Undoubtedly, the above indicator's swift growth (1.5 times over within three weeks) should be considered as a mistake, tongue-slip or misprint, but no corrections or denials on the part of either the Joint Staff or editorial staff of the defense agency's mass-media followed in the period after the publication. So, within December 2013 the key target indicators of fulfillment of the state armament program and the state defense order changed for the better by 2-12 p.p., having exceeded across most services of the armed forces indicators of equipment with modern weaponry of the armed forces of the world's leading countries; early in 2011 the Ministry of Defense repeatedly stated that they were in the range of $30-50 \%{ }^{2}$.

Unfortunately, a year later the Ministry of Defense was unable to answer questions which arose at that time -- no relevant data on equipment of the armed forces with weaponry was given in the 2013 Annual Statistical Book.

At the same time, the work carried out by experts of the Department of Economic Analysis and Forecasting of the Ministry of Defense deserves high praise - everything that is not related to the actual full strength and equipment of the armed forces, volumes of procurement of armaments and military equipment and the military agency's budget in general is done professionally.

It is to be noted that quite complete data on volumes of budget funding of the armed forces' logistical support and military traffic, real property management and R\&D carried out by the Ministry of Defense are of great interest. However, there are significant discrepancies between newly published data on expenditures related to logistical support in the above statistical book and the earlier provided data on execution of the federal budget (Table 1). Factors behind the above discrepancies are not clear and need to be explained.

\section{STATISTICAL DISCREPANCIES BETWEEN THE LAW ON EXECUTION OF THE FEDERAL BUDGET AND THE STATISTICAL BOOK OF THE MINISTRY OF DEFENSE, BILLION RB AND \%}

Table 1

\begin{tabular}{|c|c|c|c|c|}
\hline \multirow{2}{*}{$\begin{array}{l}\text { Type of expenditures (page } \\
\text { of the statistical book) }\end{array}$} & \multirow{2}{*}{$\begin{array}{c}\text { Law } \\
\text { (billion Rb) }\end{array}$} & \multirow{2}{*}{$\begin{array}{c}\text { Statistical } \\
\text { book } \\
\text { (billion Rb) }\end{array}$} & \multicolumn{2}{|c|}{ Difference } \\
\hline & & & Billion $\mathrm{Rb}$ & $\%$ \\
\hline Military traffic (p. 56) & 17411.1 & 16517.8 & -893.3 & -5.1 \\
\hline Material support (p. 65) & 20636.2 & 23395.3 & 2759.1 & 13.4 \\
\hline Food provision (p. 74) & 54693.2 & 48858.1 & -5835.1 & -10.7 \\
\hline Lubricants provision (p. 80) & 59996.5 & 63926.7 & 3930.2 & 6.6 \\
\hline TOTAL & 152737.0 & 152697.9 & -39.1 & 0.0 \\
\hline
\end{tabular}

Source: The Statistical Book of the Ministry of Defense; Federal Law No.289-FZ of 4 October 2014 on Execution of the 2013 Federal Budget; Findings No. 3-3-04/16-1 of 30 September 2014 of the Committee on Defense and Security of the Federation Council.

1 A. Alexandrov. The First-Hand Information on Defense // Krasnaya Zvezda. 2013. 14 December.

2 In the new State Armament Program, priority is attached to high-tech samples // National Defense. 2011. March (No. 3). 
The International Military Statistics section is compiled by the authors of the book on the basis of materials taken from foreign sources, but in case of Russia the official number of servicemen of the armed forces is stated as $1 \mathrm{~m}$ persons, while according to The Military Balance, annual statistical book used as a foreign source that number amounts to 845,000 persons. Though on the basis of the results of 2013 the Ministry of Defense of the Russian Federation reported that "for the first time in the past few years the full strength of the armed forces amounted to $82.7 \% \aleph^{1}$, that is, the actual number of servicemen was equal to 827,000 persons, in the new annual statistical book they preferred to ignore that fact and used the official upper limit of the strength of the armed forces.

Despite the above faults, in general the 2013 statistical book of the Ministry of Defense is a major step forward in the Russian military reform and if unjustified secrecy is overcome and the statistical military-judicial data (data on crimes) and the data on accidents are included it will definitely become a valuable source of information and instrument of management both for the country's military and political leadership and the public in general.

1 The Operations Plan of the Ministry of Defense of the Russian Federation. The 2013 Report. URL: http://mil.ru/files/files/result2013/01-planMO2013.html (the date of application: 22.01.2014). 